\title{
Pengaruh harga CPO, harga minyak mentah dunia, harga karet dunia dan kurs terhadap defisit neraca transaksi berjalan Indonesia
}

\author{
Bondan Noviantoro; Emilia; Yohanes Vyn Amzar* \\ Prodi Ekonomi Pembangunan, Fakultas Ekonomi dan Bisnis, Universitas Jambi \\ *E-mail korespondensi:yovaz@unja.ac.id
}

\begin{abstract}
Current account balance is a measuring instrument about Indonesian international trade, but current account balance tends to be unbalanced. This resource conducted to analyze influence of CPO price, world crude oil price, world rubber price, and exchange rate to Indonesian current account deficit. The Data which used is secondary data and sourced from World Bank and Indonesian Bank that have year period 2010Q1-2015Q4. Analytical tool that used is multiple linear regression analysis. Based on the result of the research that variable price of $C P O$, world crude oil price, world rubber price, and exchange rate jointly significant effect to Indonesian current account deficit. Determination coefficient value of 0,716 which means the effect of variations in changes in independent variables to the dependent variable is equal to 71,60\% and is affected by the outside research variables. Statistic result $t$ shows variable price of CPO and exchange rate partially significant effect while world crude oil price and world rubber price do not partially significant effect.
\end{abstract}

Keywords: The Price of CPO, Crude Oil, Rubber, Exchange Rate, Current Account

\begin{abstract}
Abstrak
Neraca transaksi berjalan adalah sebuah alat ukur tentang perdagangan internasional Indonesia, namun kondisi neraca transaksi berjalan cenderung tidak seimbang. Penelitian ini bertujuan untuk menganalisis pengaruh harga $\mathrm{CPO}$, harga minyak mentah dunia, harga karet dunia dan kurs terhadap defisit neraca transaksi berjalan Indonesia. Data yang digunakan adalah data sekunder dan bersumber dari World Bank dan Bank Indonesia dengan periode tahun 2010Q1-2015Q4. Alat analisis yang digunakan adalah analisis regresi liniear berganda. Berdasarkan hasil penelitian diperoleh bahwa variabel harga CPO, harga minyak mentah dunia, harga karet dunia dan kurs secara bersamasama berpengaruh signifikan terhadap defisit neraca transkasi berjalan Indonesia. Nilai Koefisien determinasi sebesar 0,716 yang berarti pengaruh variasi perubahan variabel independen terhadap variabel dependen sebesar $71,60 \%$ dan sisanya dipengaruhi variabel diluar penelitian. Hasil uji statistik t menunjukkan variabel harga CPO dan kurs berpengaruh signifikan secara parsial sedangkan harga minyak mentah dunia dan harga karet dunia tidak berpengaruh signifikan secara parsial.
\end{abstract}

Kata kunci: harga, CPO, minyak mentah, karet, kurs, transaksi berjalan.

\section{PENDAHULUAN}

Dalam usaha pemenuhan kebutuhan dalam negeri yang tidak dapat dipenuhi sendiri, setiap negara melakukan kegiatan perdagangan internasional.Perdagangan internasional didefinisikan sebagai perdagangan antar atau lintas negara, yang 
mencakup ekspor dan impor.Perdagangan internasional dibagi menjadi dua kategori, yakni perdagangan barang (fisik) dan perdagangan jasa (Tambunan, 2001).Dengan adanya kegiatan perdagangan internasional tersebut, berarti tiap negara telah membuka kegiatan perekonomian negaranya, termasuk Indonesia.

Kegiatan transaksi internasonal tersebut dicatat dalam Neraca Pembayaran (Balance of Payment). Neraca Pembayaran adalah catatan yang sistematis tentang transaksi ekonomi internasional antara penduduk negara itu dengan negara lain dalam jangka waktu tertentu (Nopirin, 2010).

Neraca Pebayaran (NP) terdiri dari transaksi berjalan, yakni jumlah saldo dari neraca perdagangan, neraca jasa, dan transaksi sepihak, neraca lalu lintas modal, selisih yang belum (error andomission, atau E\&O), dan neraca lalu lintas moneter (Tambunan, 2001).

Nearaca transaksi berjalan pada kegiataannya dapat mengalami keadaan surplus dan defisit.Surplus neraca transaksi berjalan terjadi ketika ekspor lebih besar daripada impor.Namun ketika yang terjadi sebaliknya, yatu impor lebih besar daripada ekspor yang terjadi adalah defisit neraca transaksi berjalan. Negara yang mengalami defisit transaksi berjalan rentan terhadap capital outflows dan juga menjadi peminjam neto dari negara lain karena negara tersebut membutuhkan modal untuk membiayai defisit tersebut.

Dalam beberapa tahun terakhir, Indonesia megalami defisit neraca transksi berjalan.Keadaan ini terjadi pada periode 2013 kuartal 1 sampai 2015 kuartal 4.Defisit ini terus terjadi tanpa mengalam perbaikan yang signifikan.

Gambar 1 Perkembangan Neraca Transaksi Berjalan Indonesia periode 2013Q1 2015Q4.

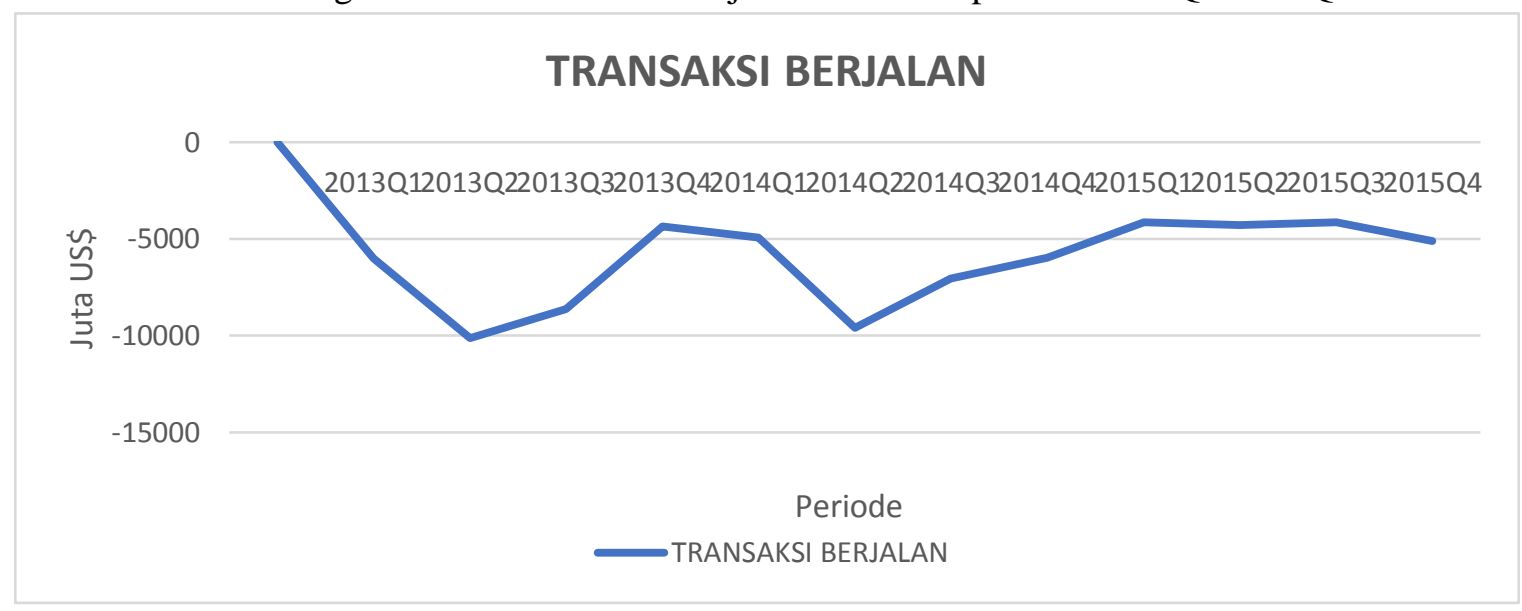

Sumber: Statistik Ekonomi danKeuangan Indonesia: Bank Indonesia.

Indonesia sudah mengalami defisit neraca transaksi berjalan semenjak tahun 2011 kuartal 4 dan terus mengalami defisit hingga periode 2015 kuartal 4. Berdasarkan dari gambar I.1 dapat dilihat bahwa neraca transaksi berjalan periode 2013Q1-2015Q4 mengalami fluktuasi tetapi tetap mengalami keadaan defisit dengan trend yang cenderung meningkat.Pada tahun 2013, keadaan impor migas mengalami fluktuasi tetapi tetap dalam keadaan impor lebih besar daripada jumlah ekspor.Sedangkan dalam sektor jasa-jasa, pada tahun 2013 jumlah impor jasa juga lebih besar ketimbang jumlah ekspor yang ada.

Jumlah Ekspor Indonesia turun drastis sejak tahun 2011, dikarenakan lambatnya pertumbuhan ekonomi global, terutama berkurangnya kecepatan pertumbuhan pembangunan Republik Rakyat Tiongkok yang mana adalah mitra dagang Indonesia. Jenis komoditas yang diperdagangkan oleh Indoesia adalah barang-barang mentah atau barang baku seperti cpo, minyak mentah dan karet alam. Indonesia sebagai salah satu 
negara yang memiliki lahan perkebunan sawit, menjadikannya sebagai salah satu negara penghasil crude palm oil (selanjutnya di sebut CPO) terbesar di dunia.

Ketika terjadinya kegiatan perdagangan internasional, yakni bertemunya antara eksportir dan importir beserta dengan terdapatnya barang dan kesepakatan yang dibuat maka terciptanya harga komoditas tersebut.CPO, minyak mentah dan karet alam adalah beberapa komoditas yang paling banyak di perdagangkan karena dari satu jenis komoditas ini dapat menghasilkan turunan komoditas lainnya.

Gambar 2 Perkembangan Harga CPO, Minyak Mentah, KaretDunia periode 2010Q1-2015Q4

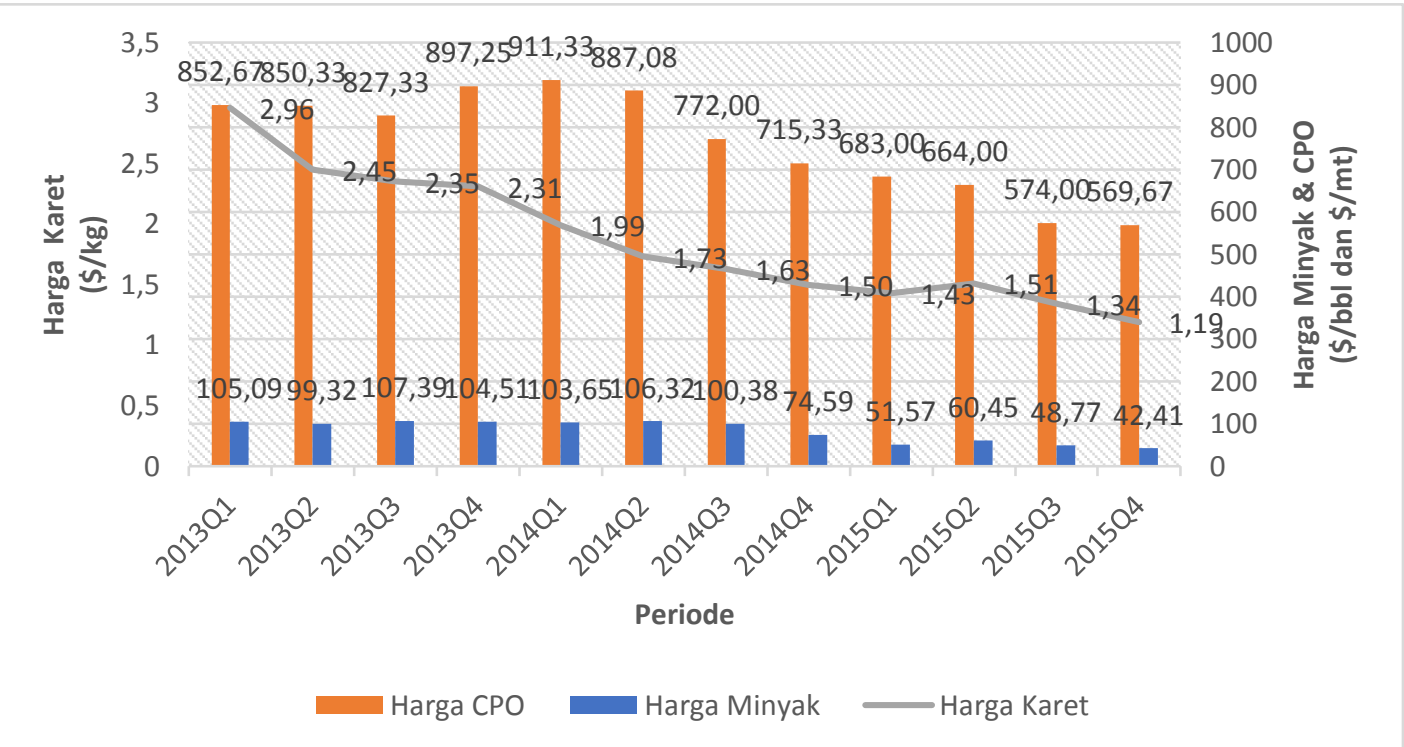

Sumber : World Bank Commodity Price (data diolah)

Dari data World Bank terlihat bahwa harga CPO dunia cenderung mengalami menurunan dari waktu ke waktu, penurunan ini merupakan dampak dari beberapa faktor yang sedang terjadi di dunia. Hinggal Kuartal akhir 2015, beberapa komoditas minyak nabati mengalami penurunan harga termasuk harga CPO. Melemahnya permintaan negara importir CPO juga salah satu faktor menurunnya harga CPO dunia.

Selain penghasil dan menjadi negara pengekspor CPO, Indonesia juga merupakan negara pengekspor minyak mentah dan karet alam.Dengan naik turunnya harga minyak dunia ini menjadi perhatian khusus bagi negara importir minyak mentah dan juga bagi negara eksportir minyak mentah.

Naik turunnya harga minyak mentah dunia memiliki dampak terhadap hampir disegala aspek, seperti studi yang pernah dilakukan pasca oil shock tahun 1970-an menemukan bahwa guncangan tersebut berpengaruh negatif dan signifikan terhadap PDB dan juga guncangan harga minyak dunia menjadi penyebab terjadinya resesi ekonomi yang terjadi di Amerika Serikat dan sejumlah negara di Eropa (Hamilton, 1983, 1988, 1996). Dengan berpengaruhnya harga minyak dunia terhadap PDB dan penyebab ternjadinya resesi ekonomi, maka fluktuasi harga minyak dunia juga berdampak pada terjadinya defisit neraca transaksi berjalan, khususnya nerca transaksi berjalan Indonesia.Salain minyak dunia, karet juga merupakan salah satu komoditas utama ekspor Indonesia. Karet merupakan komoditas yang paling banyak digunakan di dalam pembuatan hampir seluruh peralatan di seluruh dunia. Jenis karet dibedakan menjadi 2 tipe, karet alam dan sintetis. Karet alam di peroleh dari getah pohon karet, sedangka karet sintetis dibuat dari minyak mentah. Harga karet dunia, dari periode 2010-2015 mengalami fluktuasi, dengan trend yang menurun lebih dominan. 
Untuk melakukan kegiatan pembayaran atas pembelian barang dan jasa, maka diperlukan sebuah mata uang yang sudah ditetapkan atau sudah disetuji dalam kegiatan perdagangan internasional.US\$ adalah mata uang yang diterima dalam kegiatan transaksi perdagangan internasional. Ketika akan membayarkan maka tiap negara perlu mengkonversikan mata uang mereka ke US\$, bukan menggunakan mata uang asli.Oleh karena itu, negara pengekspor dan pengimpor memerlukan mata uang standar untuk melakukan transaksi perdagangan internasional seperti US Dollar (Dachliani, 2006).

Perubahan nilai tukar yang terjadi, baik apresiasi maupun depresiasi akan mempengaruhi kegiatan ekspor dan impor barang-barang di negara Indonesia. Hal itu dikarenakan mata uang US Dollar masih merupakan mata uang yang mendominasi pembayaran perdagangan global (Nezky, 2013).

Ketika rupiah mengalami depresiasi berdapak pada naiknya harga barang luar negeri sehingga mengurangi impor oleh karena itu hal ini membuat neraca transaksi berjalan menjadi surplus. Jika yang terjadi adalah apresiasi pada mata uang rupiah, maka harga barang luar negeri menjadi lebih murah ketimbang harga barang luar negeri karena terjadi inflasi.Hal ini menyebabkan impor lebih banyak dilakukan ketimbang ekspor (Sukirno. 2010).

Berdasarkan latar belakang tersebut, penelitian ini bertujuan untuk menganalisis pengaruh harga $\mathrm{CPO}$, harga minyak mentah dunia, harga karet dunia dan kurs terhadap defisit neraca transaksi berjalan Indonesia?

\section{TINJAUAN PUSTAKA}

\section{Neraca Pembayaran}

Neraca Pembayaran terdiri dari transaksi berjalan, yakni jumlah saldo dari neraca perdagangan, neraca jasa, dan transaksi sepihak, neraca lalu lintas modal, selisih yang belum (error andomission, atau E\&O), dan neraca lalu lintas moneter (Tulus Tambunan, 2001). Bank Indonesia selaku otoritas moneter di Indonesia di dalam Metodologi Neraca Pembayaran Indonesia (NPI), menjelaskan bahwa pencatatan transaksi dalam neraca pembayaran dilakukan secara system double entry. Dengan sistem ini, setiap transaksi ekonomi yang terjadi dicatat pada dua entry yang berbeda dengan nilai yang sama. Kedua entry tersebut dicatat sebagai transaksi debit dan kredit sesuai dengan praktik pembukuan yang berlaku umum. Jika prinsip double entry yang diterapkan untuk setiap transaksi ekonomi maka jumlah keseluruhan entry dalam NPI akan sama dengan nol.

Dumairy (1996) mengatakan bahwa dalam konteks neraca pembayaran ada beberapa macam pengertian seimbang (balanced). Biasanya yang terjadi ialah ketidakseimbangan dalam unsur yang satu diimbangi dengan ketidakseimbangan lawannya dalam unsur yang lain. Walaupun pada akhirnya secara total neraca pembayaran tadi akan seimbang, namun dinamika ketidakseimbangan ketidakseimbangan antar unsurnya itulah yang justru menarik dan penting untuk ditelaah. Bertolak dari dinamika ketidakseimbangan itulah neraca pembayaran dikaji untuk menilai prestasi suatu negara dalam hubungan ekonominya dengan pihak luar negeri. Dinamika ketidakseimbangan itulah yang dijadikan dasar untuk mengenali apakah dan dalam hal apa negara yang bersangkutan memperoleh surplus ataukah mengalami defisit dalam kegiatan ekonomi internasionalnya.

\section{Neraca transaksi berjalan}

Neraca transaksi berjalan mencatat pengeluaran dan penerimaan (ekspor dan impor) barang dan jasa bersama-sama dengan transfer neto. Transaksi berjalan memberikan gambaran tentang nilai transaksi yang diakibatkan oleh kegiatan perdagangan barang dan jasa (Sukirno, 2008).Neraca transaksi berjalan adalah gabungan dari neraca 
perdagangan (balance of trade) yang merupakan selisih antara ekspor dan impor barang.Kemudian neraca jasa-jasa, yang merupakan selisih ekspor jasa dan impor jasa.

Apabila ekspor lebih besar dari impor maka terjadi surplus neraca transaksi berjalan, yaitu apabila penerimaan dari perdagangan barang dan jasa serta transfer lebih besar dari pembayarannya. Apabila impor lebih besar dari ekpsor yang terjadi adalah defisit neraca transaksi berjalan dan penerimaan dari perdagangan barang dan jasa serta transfer lebih kecil dari pembayarannya (Dornbusch, 2004).

Sebuah neraca transaksi berjalan yang defisit mengindikasikan bahwa sebuah negara lebih banyak melakukan impor ketimbang ekspor.Hal ini menandakan bahwa, negara tersebut masih belum bisa memenuhi semua kebutuhan di dakam negerinya. Kelebihan melakukan impor barang dan jasa yaitu dapat mengurangi cadangan devisa yang ada. Pada kasus di Indonesia, Indonesia tidak terlalu banyak melakukan ekspor yang mana dapat menambah cadangan devisa jadi cadangan devisa yang dimiliki tidak terlalu banyak, tapi lebih banyak mengurangi cadangan devisa yaitu terlalu banyak melakukan impor.

Meski definisi neraca transaksi berjalan bisa dikatakan normal untuk negara yang sedang berkembang, tapi jika dibiarkan terus menerus tanpa dilakukannya sebuah kebijakan untuk memperbaikinya, maka akan dikatakan berbahaya bagi sebuah negara tersebut. Salah satu barometer untuk mengukur kemampuan perekonomian suatu bangsa dalam menopang transaksi-transaksi internasional adalah dengan melihat neraca transaksi berjalan. Defisit neraca berjalan mengindikasikan adanya ketidakseimbangan eksternal, dan apabila jumlahnya terlalu besar dan berlangsung terus menerus akan mengakibatkan terjadinya currency crisis (Evan Lau dkk, 2003).

Beberapa faktor yang mempengaruhi defisit neraca transaksi berjalan dapat dirangkum sebagai berikut:

a. Perdagangan internasional

Selisih antara penawaran domestik dan permintaan domestik dan permintaan domesttik yang disebut dengan kelebihan penawaran (excess supply) merupakan volume ekspor komoditi dari negara tertentu ke negara lain. Sedangkan kelebihan penawaran dari negara tersebut merupakan permintaan impor bagi negara lain (excess demand) atau kelebihan permintaan.

Salvatore (1997), selain dipengaruhi oleh permintaan dan penawaran komoditas itu sendiri, ekspor komoditas juga dipengaruhi oleh faktro pasar dunia seperti harga komoditas itu sendiri, jumlah komoditas dan komoditas subtitusinya serta hal-hal yang mempengaruhi harga baik sevara langsung atau tidak.Dalam teori ekspor (Salvatore, 1997), ekspor suatu negara merupakan selisih antara produksi atau penawaran domestik dikurangi dengan konsums atau permintaan domestik negara yang bersangkutan ditambah dengan stok tahun sebelumnya.

Hubungan antara harga terhadap ekspor adalah berhubungan secara negatif. Semakin tinggi suatu harga komoditas maka permintaan tersebut semakin berkurang, cateris paribus (Lipsey,1995).

b. Harga

Kuantitas permintaan suatu komoditas berhubungan secara negatif yang berarti semakin tinggi harga suatu komoditas maka jumlah permintaan terhadap komoditas tersebut akan semakin berkurang, cateris paribus (Lipesy, 1995). Harga suatu komoditas dapat berubah-ubah dalam jangka waktu tertentu, dan perubahan harga ini dapat merubah jumlah permintaan barang suatu komoditas atau disebut sebagai elastisitas permintaan atau suatu ukuran kuantitatif yang menunjukkan besarnya pengaruh perubahan harga terhadap permintaan suatu komoditas (Sugiarto, 2007). 
c. Kurs

Kurs atau nilai tukar suatu mata uang adalah nilai tukar mata uang suatu negara terhadap negara asing lainnya (Thobarry, 2009).Jadi, nilai tukar adalah perbandingan mata uang dalam negeri terhadap mata uang asing, begitu pula sebaliknya. Menurut Anwary (2011), "nilai tukar biasanya berubah-ubah, perubahan kurs ini dapat berupa depresiasi atau apresiasi. Depresiasi rupiah terhadap dollar AS artinya suatu penurunan harga rupiah terhadap dollar AS.Sedangkan apresiasi rupiah terhadap dollar AS artinya penguatan nilai rupiah terhadap dollar AS".

Perubahan nilai kurs diakibatkan oleh faktor permintaan dan penawaran. Permintaan akan valuta asing (valas) berasal dari pemegang uang dalam negeri yang memerlukan valas untuk membeli barang dan jasa luar negeri. Penawaran valuta asing berasal dari orang asing atau pihak luar negeri yang hendak membeli barang dan jasa dalam negeri (ekspor) yang dibayar dalam mata uang dalam negeri (Kamaluddin, 1987).

Salah satu yang mempengaruhi neraca transaksi berjalan adalah nilai tukar.Pada saat nilai tukar rupiah terhadap dolar AS mengalami depresiasi, berarti terjadi penunurunan nilai mata uang rupiah. Hal ini menyebabkan naiknya harga barang luar negeri atau harga barang dalam negeri lebih murah, dalam hal ini maka sebuah negara akan mengurangi kegiatan impor, neraca transaksi berjalan akan menjadi surplus. Begitu pula sebaliknya, jika rupiah mengalami apresiasi, maka harga barang luar negeri relative lebih murah ketimbang harga barang dalam negeri, hal ini membuat impor lebih dominan ketimbang ekspor.Kelebihan impor inilah yang menyebabkan defisit neraca transaksi berjalan.

Pengaruh perubahan nilai tukar, dapat dilihat dari definisi neraca perdagangan yang didiferensiasi terhadap nilai tukar. Asumsi bahwa depresiasi kurs riil akan memperbaiki transaksi berjalan suatu negara akan dapat diterima jika keabsahan asumsi ini ditentukan oleh respon volume ekspor dan impor terhadap perubahan kurs riil tersebut. Kondisi Marshall-Lerner (Marshall-LernerCondition) menyatakan bahwa, ceteris paribus, suatu depresiasi riil bisa memperbaiki kondisi neraca berjalan apabila volume ekspor dan impor cukup elastis terhadap perubahan kurs riil tersebut (Krugman, 2000; Salvatore,2004).

\section{METODE PENELITIAN}

Jenis data yang digunakan dalam penelitian ini adalah data sekunder yaitu jenis time series periode 2010Q1-2015Q4. Sumber data diperoleh dari Bank Indonesia (BI), World Bank Commodity Price. Untuk menganalisis pengaruh harga CPO dunia, harga minyak dunia, harga karet dunia dan perubahan kurs terhadap defisit nerasa transaksi berjalan Indonesia digunakan alat analisis persamaan regresi linear berganda OLS dengan model sebagai berikut:

$\begin{array}{ll}\text { DNTB }_{t}=\beta_{0} & +\beta_{1} P C P O_{t}+\beta_{2} P M I N Y A K_{t}+\beta_{3} P K A R E T_{t} \\ \text { Keterangan: } & \\ \text { DNTB }_{t} & : \text { Defisit neraca transaksi berjalan Indonesia } \\ \beta_{0} & : \text { Konstanta } \\ \text { PCPO }_{t} & : \text { Harga CPO dunia } \\ \text { PMINYAK }_{t} & : \text { Harga minyak dunia } \\ \text { PKARET }_{t} & : \text { Harga Karet Dunia } \\ \text { KURS }_{t} & : \text { Perubahan Kurs. } \\ \mu & : \text { pengganggu/ error terms }\end{array}$


Definisi operasional dalam model adalah sebagai berikut:

1. Harga CPO dunia adalah harga jual CPO di dunia yang dapat berubah dalam kurun waktu tertentu dan jumlah permintaan yang ada di dunia. Satuan yang digunakan adalah US\$/mt (metric ton).

2. Harga Minyak Mentah Dunia adalah harga spot jual rata-rata harga untuk komoditas minyak mentah. Satuan yang digunakan adalah US\$/bbl (barrel).

3. Harga Karet Dunia adalah harga jual terhadap komoditas karet dunia. Jenis yang digunakan adalah karet TSR20. Satuan yang digunakan adalah US\$/kg.

4. Nilai tukar suatu mata uang atau kurs adalah nilai tukar mata uang suatu negara terhadap negara asing lainnya Satuan yang digunakan adalah Rp/US\$.

5. Neraca transaksi berjalan adalah gabungan antara neraca perdagangan dan neraca jasa-jasa yang dicatat atas pengeluaran dan penerimaan (ekspor dan impor) barang dan jasa bersama-sama dengan transfer neto. Satuan yang digunakan dalam Juta US\$.

\section{HASIL DAN PEMBAHASAN} berikut:

Estimasi model defisit neraca transaksi berjalan Indonesia diberikan sebagai

$$
\begin{gathered}
\text { DNTB }_{t}=4420,065+2,196 P C P O_{t}-1,378 P M I N Y A K_{t}+2360,640 P K A R E T_{t} \\
-419,287 K_{U R S}
\end{gathered}
$$

$F=12,01$

$R^{2}=0,7160$

Uji statistik $\mathrm{F}$ digunakan untuk mengetahui pengaruh variabel bebas secara bersama-sama (simultan) terhadap variabel terikat. Kesimpulan uji $\mathrm{F}$ diperoleh dengan membandingkan antara F-statistik dengan F-tabel pada taraf signifikansi $\alpha=5 \%$.

Dari hasil estimasi diperoleh nilai F-statistik sebesar 12,01 yang lebih besar dari nilai F-tabel = 2,93 (df1: 4, df2:18), sehingga dapat disimpulkan bahwa harga CPO, harga minyak mentah dunia, harga karet dunia dan kurs mempengaruhi secara simultan terhadap defisit neraca transaksi berjalan Indonesia. Nilai koefisien determinasi $\left(\mathrm{R}^{2}\right)$ sebesar 0,716. Angka tersebut menunjukkan besarnya pengaruh variasi perubahan harga CPO, harga minyak mentah dunia, harga karet dunia dan kurs terhadap defisit neraca transkasi berjalan Indonesia adalah sebesar $71,60 \%$ dan sisanya sebesar $28,40 \%$ dipengaruhi oleh variabel lain di luar penelitian ini.

Selanjutnya, pengujian secara parsial melalui uji t diberikan sebagai berikut:

\begin{tabular}{l||cc||l}
\hline \multicolumn{1}{c||}{ Variabel } & $\begin{array}{c}\text { Probabilitas } \\
\text { t-hitung }\end{array}$ & $\alpha 5 \%(0,05)$ & \multicolumn{1}{|c}{ Keterangan } \\
\hline $\mathrm{C}$ & 0,6233 & $>\alpha 5 \%(0,05)$ & Tidak Signifikan \\
\hline Harga CPO & 0,7676 & $>\alpha 5 \%(0,05)$ & Tidak Signifikan \\
\hline $\begin{array}{l}\text { Harga Minyak } \\
\text { Mentah Dunia }\end{array}$ & 0,0016 & $<\alpha 5 \%(0,05)$ & Signifikan \\
\hline Harga Karet Dunia & 0,0410 & $<\alpha 5 \%(0,05)$ & Signifikan \\
\hline Kurs & 0,4459 & $>\alpha 5 \%(0,05)$ & Tidak Signifikan \\
\hline
\end{tabular}

Berdasarkan uji parsial (uji t) terlihat bahwa harga minyak mentah dunia dan harga karet dunia memiliki pengaruh yang signifikan terhadap defisit neraca transaksi berjalan Indonesia. Koefisien regresi sebesar -1,378, menunjukkan bahwa apabila harga 
minyak mentah dunia naik sebesar $1 \mathrm{US} \$ / \mathrm{bbl}$, akan diikuti dengan penurunan defisit neraca transaksi berjalan indonesia sebesar -1,378 Juta US\$. Nilai ekspor minyak mentah Indonesia mengalami penurunan dari periode ke periode, nilai ekspor neto minyak mentah Indonesia bernilai negatif atau nilai impor lebih besar dari nilai ekspor. Ketika melakukan impor dengan tujuan untuk memenuhi kebutuhan dalam negeri, maka akan mengurang cadangan devisa. Dengan tetap melakukan impor minyak mentah maka akan mengurangi nilai neraca transaksi berjalan atau akan meningkatkan defisit neraca transaksi berjalan karena, hal ini dikarenakan impor minyak mentah Indonesia lebih besar dari ekspor minyak mentah.

Nilai koefisien harga karet dunia sebesar 2360,640. Artinya apabila harga karet dunia naik sebesar 1 US\$/kg, maka akan diikuti dengan kenaikan defisit neraca transaksi berjalan indonesia sebesar 2360,640 Juta US\$. Indonesia sebagai salah satu produsen karet mentah dunia akan mendapatkan keuntungan ketika harga karet mentah mengalami kenaikan, karena harga jual di pasar akan tinggi. Tetapi fenomena yang terjadi selama masa pengamatan adalah harga karet dunia lebih cenderung mengalami penurunan dan diikuti dengan menurunnya nilai ekspor karet mentah Indoneisa. Nilai karet mentah memang lebih rendah karena masih bersifat sebagai bahan baku, harga produk olahan karet akan lebih mahal dikarena meningkatnya harga karet mentah sebagai bahan utama dalam produk olahan tersebut, yang mengindikasikan akan meningkatkan defisit neraca transaksi berjalan indonesia.

Harga CPO tidak menunjukkan pengaruh yang signifikan terhadap defisit neraca pembayaran. Jika dilihat dari volume ekspor CPO Indonesia yang cenderung mengalami penurunan selama masa pengamatan dan dengan volume impor CPO Indonesia yang selama pengamatan jauh lebih kecil dari volume ekspor maka hal ini meningkatkan ekspor neto CPO Indoenesia.

Variabel kurs juga tidak menunjukkan pengaruh yang signifikan terhadap defisit neraca pembayaran di Indonesia. Selama masa pengamatan didapat bahwa kurs Rupiah relatif stabil.Ketika rupiah mengalami depresiasi berdapak pada naiknya harga barang luar negeri sehingga mengurangi impor oleh karena itu hal ini membuat neraca transaksi berjalan menjadi surplus. Jika yang terjadi adalah apresiasi pada mata uang rupiah, maka harga barang luar negeri menjadi lebih murah ketimbang harga barang luar negeri karena terjadi inflasi.Hal ini menyebabkan impor lebih banyak dilakukan ketimbang ekspor.Ketika kurs riil naik maka dampak yang terjadi terhadap neraca transaksi berjalan adalah akan memperbaiki atau meningkatkan nilai neraca transaksi berjalan. Sedangkan ketika nilai Kurs rill turun makan neraca transkasi berjalan justru akan memburuk dan menurun nilainya. Dengan terjadinya apresiasi dan depresiani nilai kurs terhadap harga komoditas dunia dan kegiatan ekspor impor memiliki keuntungan masing-masing.

\section{PENUTUP}

Secara simultan harga CPO, harga minyak mentah dunia, harga karet dunia dan kurs berpengaruh secara signifikan terhadap defisit neraca transaksi berjalan. Selanjutnya secara parsial harga minyak mentah dunia berpengaruh signifikan negatif dan harga karet dunia berpengaruh signifikan positif terhadap defisit neraca transaksi berjalan. Dua variabel lainnya yaitu harga CPO dan kurs, tidak menunjukkan pengaruh yang signifikan. 


\section{DAFTAR PUSTAKA}

Anwary, Ahmad Amiruddin. 2011. Prediksi Kurs Rupiah Terhadap Dollar Amerika Menggunakan Fuzzy Time Series. ProgramStudi Teknik Informatika Jurusan Matematika.Fakultas Matematika dan Ilmu PengetahuanAlam. Universitas Diponegoro. Semarang.

Dachliani, Diesy Meireni. 2006.Permintaan ImporGula Indonesia Tahun 19802003.Tesis.Semarang:Magister Ilmu Ekonomi dan Studi Pembangunan Universitas Diponegoro. Semarang.

Dornbusch, Rudi dkk. 2004. Makroekonomi: Edisi Bahasa Indonesia. MC.Graw Hill Education.

Dumairy. 1996. Perekonomian Indonesia. Erlangga. Jakarta.

Fitri, Wulan Sari. 2014. Analisis Faktor-Faktor Yang Mempengaruhi NeracaTransaksi

Berjalan : Studi Kasus Indonesia Tahun1990-2011. Economics Development Analysis Journal. Semarang.

Haryadi. 2014. Ekonomi Internasional: Teori dan Aplikasi. Jambi.

Junaidi, J., Amir, A., \& Hardiani, H. (2014). Potensi klaster agroindustri usaha mikro kecil dan menengah di Provinsi Jambi. Jurnal Perspektif Pembiayaan dan Pembangunan Daerah, 2(1), 9-20.

Kamaluddin, Rustian. 1987. Beberapa Aspek Pembangunan Nasional dan Pembangunan Daerah. Fakultas Ekonomi Universitas Indonesia. Jakarta.

Krugman, Paul R. \& Maurice Obstfeld. 2000. International Economics: Theoryand Policy. Addison-Wesley Publishing Company.

Lau, Evan, Ahmad Zubaidi Baharumshah \& Stilianos Fountas. 2003. On the Sustainability of Current Account Deficits: Evidence from Four ASEAN Countries. Journal of Asian Economics, Vol.14,Issue 3, P. 465-487.

Nezky, Mita. 2013. Pengaruh Krisis EkonomiAmerika Serikat Terhadap Bursa Saham danPerdagangan Indonesia.

Mankiw, Greg N. 2003. Macroeconomics 5th .Edition. Worth Publishers. New York.

Nopirin. 2010. Ekonomi Internasional edisi 3. BPFE. Yogyakarta.

Santosa, Budi Agus. 2010. Pengaruh Fluktuasi Nilai Tukar Rupiah Terhadap Neraca Transaksi Berjalan. Dinamika Keuangan dan Perbankan : November 2010. Semarang.

Salvatore, Dominic. 2004. International Economics. McMillan Publishing Company.

Simorangkir, Iskandar. Suseno. 2004. Sistem dan Kebijakan Nilai Tukar: Kebanksentralan. Bank Indonesia. Jakarta.

Sukirno, Sadono. 2010. Makroekonomi: Teori Pengantar. Rajawali Pers. Jakarta.

Sugiyono. 2007. Metode Penelitian Kuantitatif, Kualitatif dan R\&D. Alfabeta. Solo.

Sumiyati, Euis Eti. 2007. Analisis Faktor-Faktor Yang Mempengaruhi NeracaBerjalan Di Empat Negara ASEAN(Indonesia, Malaysia, Thailan, Filipina)Periode 1980-2007.

Tambunan, Tulus. 2001. Perdagangan Internasional dan Neraca Pembayaran. Pustaka LP3ES. Jakarta.

Thobarry, Achmad Ath. 2009. Analisis Pengaruh Nilai Tukar, Suku Bunga, Laju Inflasi dan Pertumbuhan GDP Terhadap Indeks Harga Saham Sektor Properti (Kajian Empiris Pada Bursa Efek Indonesia Periode Pengamatan Tahun 2000-2008). Program Studi Magister Manajemen Program Pascasarjana. Universitas Diponegoro. Semarang. 
Todaro, Michael P. 2003. Pembangunan Ekonomi di Dunia Ketiga. Edisi Kedelapan, Alih bahasa : Haris Munandar. Erlangga. Jakarta.

Ukhrowiyah, Nurul. 2014. Analisis Beberapa Faktor Yang Mempengaruhi DefisitNeraca Transaksi Berjalan Di Indonesia MelaluiPendekatan Error Correction Model (ECM). Program studi Ekonomi Pembangunan. Fakultas Ekonomi dan Bisnis. Universitas Muhammadiyah Surakarta.

Winarno, Wing W. 2015. Analisis Ekonomatrika dan Statistika dengan EViews: Edisi 4. UPP STIM YKPN. Yogyakarta.

Anonim. 2017. Koran Dalam Jaringan. https://m.tempo.co/read/news.

Anonim. 2015. Koran Dalam Jaringan. https://finance.detik.com/bursa-valas.

Bank Indonesia. 2016. Statistik Ekonomi dan Keuangan Indonesesia Tahun 2016:

Sektor Eksternal. Diakses pada 1 November 2016. http://www.bi.go.id/id/statistik/seki/terkini/eksternal/Contents/Default.aspx.

Bank Indonesia. Grup Neraca Pembayaran dan Pengembangan Statistik. Departemen Statistik. 2010. Laporan Neraca Pembayaran Indonesia Realisasi TW.I 2010. Diakses pada 30 Maret 2017.(Laporan Neraca Pembayaran Indonesia Realisasi TW.I 2010 http://www.bi.go.id/id/publikasi/neracapembayaran/Pages/NPI_TW\%20I\%202 010.aspx.

Bank Indonesia. Grup Neraca Pembayaran dan Pengembangan Statistik. Departemen Statistik. 2011. Laporan Neraca Pembayaran Indonesia Realisasi TW.I 2011. Diakses pada 30 Maret 2017. (Laporan Neraca Pembayaran Indonesia Realisasi TW.I

http://www.bi.go.id/id/publikasi/neracapembayaran/Pages/npi_tw111.aspx.

Badan Pusat Statistik. Ekonomi dan Perdagangan: Ekspor-Impor. Diakases pada 29 Oktober 2016. www.bps.go.id.

International Moneter Fund. IMF Data. Access to Macroeconomics and Financial Data. Diakses pada 2 November 2016. www.imf.org.

Kementrian Perindustrian. Statistik Industri. Diakses pada 27 Oktober 2016. http://www.kemenperin.go.id/statistik/peran.php?ekspor=1.

Seputar Forex. Diakases pada 14 Desember 2016. www.seputarforex.com.

World Bank. World Bank Commodity Market. Publication and Data. Prices. Diakases pada 2 November 2016. World Bank: Development Prospects Group. www.worldbank.org. 